\title{
The Recovery of a Canadian Tradition in Higher Education
}

\author{
CLAUDE T. BISSELL*
}

\begin{abstract}
Amid the present public indifference to higher education, the appearance of the Symons report was welcome, since it drew attention to national issues. Although it is important to examine the curriculum from the point of view of Canadian content, a separation of Canadian content from a particular discipline may encourage provincialism and didactism. It is more important for universities to examine the role they have played and are playing in the national life. I suggest the establishment of a group of interdisciplinary seminars at various universities across the country, staffed by existing faculty and post-doctoral students, and concerned with the examination of crucial Canadian problems.
\end{abstract}

\section{RÉSUMÉ}

Le recouvrement d'une tradition canadienne dans l'enseignement supérieur Au milieu de l'indifférence publique actuelle à l'endroit de l'enseignement supérieur, la parution du rapport Symons fut bienvenue, puisqu'il mit en valeur des questions nationales. Bien qu'il soit important d'examiner les programmes d'étude du point de vue du contenu canadien, le classement à part du contenu canadien pour une matière précise risque d'encourager le provincialisme et le didactique. Il est plus important que les universités fassent un examen du rôle qu'ils jouaient et qu'ils jouent actuellement au sein de la vie nationale. Je suggère la mise en place d'une série de séances d'étude interdisciplinaires à de diverses universités d'à travers le pays, avec un personnel nommé du corps enseignant actuel et des étudiants post-doctoraux de l'université qui s'intéressent à l'examen des problèmes canadiens critiques.

When the first section of the Report of the Commission on Canadian Studies entitled To Know Ourselves was published last fall, there was a flurry of public interest, which has now subsided. Universities are not to-day, as they were in the late 'sixties, good copy, and no doubt university administrations, especially those who recall the savage 'sixties, take

*University Professor, University of Toronto 
some satisfaction in their new state. Yet no doubt there are some nostalgic regrets about the passing of the old violent and romantic days. At least some people inside and outside the universities thought the universities were important enough to merit intense concern, and the press and public reflected that concern. Harrassed administrators, confronted with non-negotiable demands and the breakdown of familiar procedures, could find some satisfaction in reflecting on the centrality of the universities in the public consciousness, and their receptiveness to new ideas, even if the ideas often seemed to strike at the very heart of the university.

Now, although the universities continue to attract students in large numbers (although administrators can no longer flamboyantly flourish figures of expansion as they could in the post-war gold rush), they have receded from public consciousness into the decent halflight in which for over a century they had lived. But there are differences in the two obscurities. The old obscurity - say, up to the beginning of the second world war - was a genteel obscurity, the kind of obscurity that attends the activities of distinguished citizens, with an honourable lineage, impeccable respectability, and no great stake in major decisions. The new obscurity of the "seventies has a faceless quality about it. Universities are taken for granted; they are big, impersonal institutions, fitted parts in a technological society, necessary, deserving support, to be criticized, admonished, censured in the same way that we would criticize, admonish, and censure any large corporation. But they have no special status, they are not thought of as sources of new ideas, and they do not make good subjects for animated comment or lively analysis.

I exaggerate the difference, but my main point is, I think, sound. In this generally heavy and motionless atmosphere, the disturbance caused by the Report on Canadian Studies was a relief, and Professor Symons and his associates merit our gratitude for the mere fact of raising controversial questions. The very existence of the Commission and the Report was a demonstration that the universities were not impersonal, hierarchical corporations, that they were capable of self-analysis and self-criticism and did not respond simply to public pressure. But it is typical of the present atmosphere that this point was not often made in the press, and most comment implied that the universities, by nature insensitive and selfabsorbed, were being justly admonished by a righteous external authority. Still the public concern about the 'Canadianism' of the universities should be welcomed and the criticism should be seriously examined. Even if the concern is often uninformed, and its expression, harsh and unfair, it points to a general dissatisfaction with the course of the universities, and invites them to examine themselves and to clarify their goals.

I shall examine a subject that goes beyond the present emphasis on staffing and curriculum and attempts to answer the question: to what extent have our universities developed distinctive Canadian characteristics and, in the current concern with our national survival, what role can the universities play? But, first of all, I should like to make a few general and dogmatic comments on staffing and curriculum in the light of nationalist complaints. If we take specific political steps to increase the number of Canadian nationals in our universities (a step that, whatever its immediate attractions, would drive another spike into our bureaucratic coffin), we should remember that the composition of the universities, especially the new ones, was determined for several decades during the expansion period of the 'sixties. The heavy reliance then on American imports, to use football terminology, was the result not only of the paucity and weakness of our graduate schools, but of our 
lack of confidence in their performance. In our colonial heart of hearts, we believed that advanced degrees from Harvard, Stanford, Michigan, and California, glowed more brightly than advanced degrees from McGill, Toronto, Alberta and British Columbia. I think that attitude is changing, and we now have confidence in what we can do ourselves. That will be an automatic internal check on too great a reliance in staff coming from outside Canada. But it should not be a reason for relying exclusively on our own universities. I still think it is important to have staff with the advanced degrees from American and European universities (particularly staff who have taken a first degree in Canada). If nothing else, it gives staff so trained a fresh perspective on their own country, not always from a higher level. (My own advanced degree from an American university made me more aware than before of the value of the undergraduate education I had received in Canada.) And we should not shut off a modest flow of staff whose entire education was received elsewhere. I have in mind particularly staff from Great Britain and the European continent. The old universities in the east and the new universities in the west relied heavily, in their early stages, on staff from Great Britain. It was, you might argue, a reflection of imperial domination; but even imperialism has its acceptable face. And besides these imperialists often turned into nationalists far more outspoken and aggressive than the local breed. I think of many examples at my own university. Burgon Bickersteth taught at Alberta in its early days, then fashioned a remarkable career as warden of Hart House at Toronto, and in his retirement he mades even Canterbury a Canadian enclave. Barker Fairley became a great German scholar, but he was also one of the earliest supporters of the School of Seven and a founder of The Canadian Forum. Eric Arthur, from New Zealand by way of Liverpool, taught us to look at our architectural heritage and to preserve the best of it. Vincent Bladen came to Canada from Oxford in the early 'twenties; and few have done as much as he to support, advise, and direct young Canadian scholars in the social sciences. And Boyd Neel proclaimed more confidently than any native-born Canadian the excellence of our musicians. The hard and paradoxical fact is that Canadians still need outsiders to assure them that what they are doing meets world standards.

We should look at curriculum - at the study of Canadian material - in the same sympathetic, but pragmatic light. It is no service to the study of Canadian subject matter to detach it too abruptly from an established discipline. The Canadian historian must know European and American history; and the Canadian literary historian and critic cannot erect a structure on the basis of Canadian writing alone, which derives much of its strength and fascination from the adaptation of European models. An early and exclusive concentration on Canadian literature is bad for the student - it distorts his perspective and dulls his critical faculties - and bad for the scholar - it induces flatulence in critical theory. I am sceptical of an undergraduate programme in 'Canadian Studies', which is akin to other curricular developments that tie a whole range of disciplines to a particular aspect of a subject, e.g., 'women studies', - it is difficult not to turn such programmes into didactic exercises, and to make the search for truth the search for the holy grail.

Having made these reactionary remarks, I, nevertheless, declare my belief in the need in our universities to look at ourselves more searchingly and carefully and my awareness that we have done far too little in the part. And if 'Canadian Studies' means an interdisciplinary approach to the study of Canada, I think there is an important place for it, as I shall later argue, although chiefly at an advanced level. The problem with all interdis- 
ciplinary studies is that they become vital only in the mind of the individual who can fuse insights from a variety of sources. And in our present highly demarcated scheme of knowledge, it is not easy to find such a person even on a limited scale, say a scientist who reads Pratt's Towards the Last Spoke with pleasure and sensitivity, or a critic of the contemporary Canadian novel who knows the work of John Porter and Delbert Clark. An interdisciplinary approach cannot be taught, but it can be nurtured. An intensely specialized approach to a Canadian subject can be terribly misleading. Recently I took part in an informal seminar at a senior American university, where graduate students in the social sciences were following a Canadian programme. We finally turned our attention to the question of what constitutes the differences between Canada, particularly English-speaking Canada, and the United States. And as the discussion glanced over some of the old themes - parliamentary government versus the American system, an economy of natural resources versus a manufacturing economy - I thought how superficial the discussion was, in the absence of any knowledge of what really defines the quality of a country - Literature and the Arts.

I return now to my main question: "to what extent have our Universities developed distinctive Canadian characteristics, and what role can they play in clarifying what we have been and what we might become?" We can begin with some historical facts; they do not give us identifying characteristics, but they provide the base for generalization. What is clear is that from the very beginning, whether those beginnings were in the Maritime provinces, Quebec, Ontario, or the western provinces, higher education was given a high priority even at a time when the outlines of a political structure were only faintly discernible and the majority of the people were concerned with the crude mechanics of living. The two King's Colleges in the Maritimes, one at Windsor, later absorbed into Dalhousie, and the other at Fredericton (later to become the University of New Brunswick) were both founded (there is friendly disputation about dates and priority) in the 1780's, and are therefore older (as are most Canadian universities) than any of the English universities, outside, of course, of the two ancient foundations. In Quebec, the Jesuit college that was to become the University of Laval, was founded in 1635, a year before the founding of Harvard. Farther west, McGill, Queens, Toronto emerged in the early decades of the nineteenth century, although the idea of the universities goes back to the turn of the century, to a time when the English-speaking immigrants were trying to establish an alternative political structure to the one to the south that they had abandoned. The time-table in the far west was even more remarkable. The bill creating the University of Manitoba was passed in 1877 , seven years after the province was formed. British Columbia took similar action in 1890 , although the bill remained a pious declaration of intent until 1915. But Alberta and Saskatchewan, without British Columbia's sense of identity, fused legal intent and action in an extraordinary way. The two provinces were created in 1905, carved out of the North West Territories. In 1906 Alberta passed a University act; in 1907, it had a president, H. M. Tory who was to be a dominant figure in Canadian higher education for the next four decades, and in 1908 it had a habitation, five faculty, and forty-five students. Saskatchewan followed an identical sequence, one year behind at eạch stage; and it, too, chose a president, W. C. Murray, who was to give strong leadership both to his own university and to Canadian higher education.

Although Canadian universities were quickly launched and grew rapidly in numbers (by 
Confederation there were 18 degree-granting institutions), it would not be correct to say that they were popular institutions with deep roots in society. They had been launched as important protagonists in the programme of counter-revolution that was to insulate British North America from the new republic to the south. Their role was to assert indebtedness to the mother country, maintain a proper hierarchial concept of society by training its leaders, clergymen and lawyers, and to demonstrate the weakness of democratic doctrine simply by expounding the great classics of literature and philosophy. Two refreshingly forthright comments by loyalists - the people who were to shape the northern colony give a clear picture of the role of the infant universities. The first is an address to Sir Guy Carleton, Governor-in-Chief of British North America, sent to him in 1783 by five clergymen still resident in New York. ${ }^{1}$

The founding of a College or Seminary of learning on a liberal plan in that province where youth may receive a virtuous education and can be qualified for the learned professions, is, we humbly conceive, a measure of the greatest consequence, as it would diffuse religious literature, loyalty and good morals among His Majesty's subjects there. If such a seminary is not established the inhabitants will have no means of educating their sons at home, but will be under the necessity of sending them, for that purpose either to Great Britain or Ireland, which will be attended with an expense that few can bear, or else to some of the states of this continent, where they will soon imbibe principles that are unfavourable to the British tradition.

The second letter, four years later, is from Bishop Mountain, who was to be a founder of McGill, to the lieutenant-governor of Quebec.

Let me be permitted, then, to suggest the danger which may result to the political principles and to the future character as subjects of such of our young men among the higher ranks as the exigency of the case obliges their parents to send for classical education to the colleges of the United States. In these Seminaries, most assuredly, they are not likely to imbibe that attachment to our constitution in Church and State, that veneration for the Government of their country, and that loyalty to their King, to which it is so particularly necessary in the present time to give all the advantages of early predilection in order to fix them deeply both in the understanding and the heart.

Universities so conceived were not the proud possession of the common people, of farmers and small tradesmen. They were the creations of a small privileged group who embodied authority and they served the group that created them. The French-Canadian colleges were even more firmly tied to authority. They were "citadelles nationales" whose function was to produce the religious and political state by which the theocratic society of Quebec could be preserved. Under the impact of denominationalism, the universities lost their exlusive, elitist character, but sacrificed state support. State support, which meant provincial support, a condition that was elevated to a principle in the British North American Act of 1867 , was throughout the nineteenth century slight and sporadic. There was no infusion such as came to the American universities with the Morrill Act of 1862, which, through land grants, established state universities on a sound financial basis. And, although during the nineteenth century there were splendid private benefactions to Dalhousie and McGill, and, under Principal Grant, widespread support to Queens from alumni and friends, it could not be said that Canada had produced a group of privately supported universities comparable 
to those that had emerged in the United States and that gave a qualitative edge to American higher education.

During the nineteenth century Canadian universities showed little enthusiasm for accepting professional studies as part of their obligation and the initiative in establishing agricultural and engineering schools lay with the state, in sharp contradistinctions to the United States, where the Morrill Act required the universities "to teach such branches of learning as are related to agriculture and the mechanic arts." The social sciences were almost nonexistent in Canadian universities in the nineteenth century and, in some cases, until well on into this century, and formal graduate work, although recognized as a proper university activity late in the century, was ignored.

The Canadian nineteenth century tradition in higher education was not then, despite its remarkable beginnings, a subject for patriotic embroidery on a grand scale. It was characterized by a narrow élitism based on class and religion, modified but not necessarily improved by a vigorous sectarianism; inadequate financial support from the state with occasional outbursts of private philanthropy; a cool attitude to subjects of a more practical bent, engineering, agriculture, even medicine, and the social sciences; and a profound indifference to scholarship and publication. When in 1893 the president of the Royal Society of Canada, J. G. Bourinot, gave a presidential address on 'Our Intellectual Strengths and Weaknesses," with particular attention to literature, education, and the arts, he drew his modest examples from literature, and pointedly omitted scholarship ${ }^{2}$. Sir Robert Falconer's general assessment of the position of higher education in the 1880's made fifty years later was sound:

The universities had no contact with one another. Most of them had been conceived, born, and nourished for sectarian purposes, and all were very poor. Because they were poor, they were ill-nurtured, and were as a rule at odds with one another. Professors were badly paid, libraries were meagre, laboratories were few and scantily equipped, museums hardly existed. The provincial treasurers harassed by other demands for which they were afraid to tax their constituents, took advantage of the divided interests of the colleges to refuse aid impartially to all.

The 19 th century tradition was not, however, all negative. The Canadian universities, it is true, stood outside the predominant American tradition that had been bequeathed by the revolution. They persisted in the counter-revolutionary stance they had assumed at the beginning of the century, concerned with passing on specialized knowledge particularly in the humanities to a selected group of students. Their models were European, Oxford, Cambridge, the Scottish universities, Dublin, the comparatively new University of London, the University of Louvain. They were, indeed, more extensions of Europe than of the United States. This in itself was not evidence of passivity, especially when variations appeared in the new country. And revolutionary and counter-revolutionary are terms that depend upon your scale of values. One could argue that, in some respects, the Canadian universities were revolutionary in that they refused to surrender basic assumptions to the pressures of a secular, materialistic, society.

One assumption was that the study of religion was an integral part of higher education. By the middle of the nineteenth century the state had accepted the necessity for secularization in education, but it found a way, indirectly of supporting the sectarian principle. 
There never was, as there was in the United States, a clear separation of the secular and the religious. There education followed the doctrines of the enlightenment, which isolated the religious life - a valuable, powerful, but untidy area - from the working of the practical intellect.

This continuing alliance between religion and education, strong, omnipresent, but in English-Canada never explicitly defined, left behind, even after it had weakened and lost its legal force, a tradition that exercised a various and pervasive influence. It helps to account for the college tradition, directly in French Canada where the colleges, small, intimate communities, existed away from the university campus in a rural or small town setting under the immediate control of the church; indirectly in English-Canada, where the college usually had church sponsorship, and emphasized the role of the residence, inseparable from the college, as an instrument of moral and social instruction. The religious connection meant a heavy emphasis on the humanities - particularly on classics (increasingly supplanted by English in the twentieth century) and philosophy, both of which were congenial to the religious spirit, although not necessarily to sectarian orthodoxy. By the end of the nineteenth century, philosophy had become the dominant subject in both English and French universities, and it nourished the best teachers and scholars: John Watson of Queen's, George Paxton Young of Toronto, J. Clark Murray of McGill, William Lyall of Dalhousie. The rise of the social sciences diminished the role of philosophy, but it still retains a central role in Canadian universities, stronger, $I$ believe, than in American universities, at least on a comparative quantitative basis. When English studies rose to a position of dominance in the humanities, by the second decade of the twentieth century, they carried with them from the nineteenth century tradition a strong philosophical emphasis. It is significant that the two Canadian writers who have made the greatest international impact - Marshall McLuhan and Northrop Frye - have close college connections, McLuhan with the Roman Catholic College of St. Michaels, Frye with Victoria College, the voice of thoughtful methodism in the nineteenth century, and since then an exponent of protestant dissent (William Blake, the subject of Frye's first major book, would have found in Frye's college of the 'thirties and 'forties a sympathetic environment.) Both McLuhan and Frye have moved into systematic analysis and philosophical generalization from and through literary studies; and both can, on occasion, assume a prophetic stance.

No doubt, particularly in French Canada, the religious connection imposed constraints and tethered speculation, and, to a lesser extent, this was true in English Canada. But the sectarian diversity of the university also reduced the chances of a heavy, central authoritarianism and blunted the clumsy forays of the state. I recall from the early days of my administrative career a vivid illustrative incident. The 'red Dean' of Canterbury, Hewlett Johnson, was denied a platform in the central hall of the University of Toronto, chiefly because of quiet but steely protest from the Board of Governors; but he found a friendly reception in Trinity, the Church of England College, where he expounded his pastoral communism to a large, sympathetic, but critically alert student audience.

Another characteristic of the nineteenth century tradition in higher education was the continuous emphasis on prescription of subjects in the general arts course, which could be total in the French-Canadian classical college course, and a strong element in all the general courses offered in the English-speaking universities. The prescribed courses varied, but the most common group towards the end of the century was English, Latin, and Mathematics. 
In this respect the Canadian universities differed sharply from the American, which had, after President Eliot's famous formulation of 1869, embraced the elective system of free choice. A cynical observation might be that the Canadian universities had no alternative, since most of them had small staffs and a limited number of subject offerings, and could not, therefore, give a choice to students. But educational policy was also a determining factor. The Canadian university believed that higher education meant, first of all, some familiarity with a core of subjects. It is true that student choice and specialization entered into the Canadian honours course, but here there was, to a greater extent than in the United States, an emphasis on special qualifications and achievements, and in some universities, the creation from the very beginning of carefully constructed courses.

What has happened to the nineteenth century tradition? The simple answer is that it has disappeared. In the process the clear differences between Canadian and American universities have also disappeared. With increasing state domination, the Victorian compromise between religion and education yielded to the forces of secularization. With a plentitude of subjects, we have, in various degrees, embraced the elective system and, in this egalitarian age, we play down the qualitative difference between the general and the honours course. Belatedly, not until two world wars had shattered our equanimity, we accepted two cardinal American doctrines: full accessibility to the universities (which meant the progressive elimination of economic barriers), and the importance of knowledge in economic growth and social development. The acceptance of these two changes brought about the revolution of the 'fifties and 'sixties, by which Canada, in quantitative terms, advanced from a country with a minor to major commitment in higher education. No country increased more rapidly the enrolment ratios in post-secondary institutions. The emphasis on knowledge, especially on new knowledge, elevated graduate studies from the casual and informal to the central and the structured. In 1961, full-time graduate enrolment in all Canadian universities was 6,500 full-time and 3,800 part-time; in 1974-75 the comparable figures were 37,550 and 24,000, a six-fold increase. In 1973-74 nearly 2000 doctoral degrees were granted, compared to 300 in $1960-61$ !

One fresh development in this century was the strong role played by the federal government in the 'fifties and 'sixties. By the end of the Second World War provincial support of higher education had greatly increased, but it was still sporodic and inadequate, and no province had taken a strong initiative in planning for the future. The beginnings of the revolution are to be found in the Report of the Royal Commission on the National Development in the Arts, Letters, and Sciences (1951), popularly called after its chairman, Vincent Massey, which recommended a federal subsidy of universities based on the population of each of the provinces - a recommendation immediately accepted by the St. Laurent government, steadily increased during the 'fifties and 'sixties until the Federal-Provincial fiscal arrangements Act of 1967 stabilized the federal contribution at an amount equal to fifty percent of post-secondary operating expenditures. When the government in 1957 implemented the Report's major recommendation, the establishment of a Council for the Arts, Letters, Humanities and Social Sciences," it directed that half the original endowment, $\$ 50,000,000$, should be used to subsidize university buildings in the areas of interest to the council.

The Report, which, as I have said, touched off the revolution, was not inspired by a revolutionary gospel. The commissioners were concerned with the preservation and strengthening of liberal education rather than with the expansion of the universities. Louis St. 
Laurent spoke for the Commission when he declared the "their [the universities] highest service is to education men and women in that liberal human tradition which is the true glory of our Christian civilization." ${ }^{3}$ But with the awakening of the province to their responsibilities in higher education, the emphasis shifted to numbers, and the strengthening of professional faculties.

The revolution meant that Canadian universities were swept into the American orbit. And there were, as a result, great advances, most markedly in the field of advanced studies and research. Research, formerly the concern of a few individuals working on their own, was systematized and given a support never before experienced. Although there were doubts about the maintenance of standards when new institutions were created overnight and old ones accepted enrolments never contemplated in the most expansive projections, there could be no doubt that Canadian universities had become stronger, with better laboratories, more adequate libraries, and a more various and scholarly staff.

But the new university seemed to lack self-confidence; and a popular literature of criticism grew up that was often harsh and cynical. Whatever the defects of the old university, it had a simple appeal: it stood at the summit of our educational system and spoke for quality. But the new university seemed to lack any simple persuasive goal, outside the obvious one of preparing a proportion of young people for the professions. The old university of the nineteenth century (which persisted until the beginning of the first world war) seemed to have such a mission, although it was seen through a glass darkly. It was, in a general sense, to preserve cultural values, and to keep society in touch with the eternal verities. That sounds quaint and victorian to-day; cultural values, we would say, are more immediately the concern of our writers and artists, our network of theatres and concert halls, and even of our magazines and newspapers. The university seems to have become a complex, impersonal corporation busily engaged in a number of activities all related, in varying degrees, with the knowledge industry. Even that concern is obscured by a multiplicity of activities: faculty are more vividly trade unionists, consultants, national and international bureaucrats than they are teachers, thinkers, and scholars. Administrators are politicians trying to improve the university's position in an increasing long list of social priorities. There is a gap at the centre, or there doesn't seem to be a centre at all.

I make these comments in no despairing mood, because I think that Canadian universities, stronger than they were before, will reassert their leadership. Although we acknowledge that the recent revolution - like the revolution in higher education throughout the world - was essentially an American revolution, we need to rediscover our tradition and reshape them for our day. I have said that most of the specific ways in which those traditions showed themselves have disappeared, and are not likely to return in their old form. But the spirit is still there: a humanistic emphasis, not so much an emphasis on the humanities as subjects (although I personally welcome that) as an emphasis on the necessity to make all knowledge human, to relate it to the fundamental question of what constitutes the good life; a belief that no matter how various the university may become, how divers and different student and staff may be, the central concern must be with analysis and criticism, disinterested, in that it strives to eliminate prejudice and self interest, endowed with a perspective that only a knowledge of what has gone before can give and with the concern that only an awareness of the present can inspire.

No one in the university would deny the ideal, but we do little to give it a setting in 
which it would flourish. Perhaps in the graduate school, but the graduate school is tendrilled with regulations and cluttered with the paper fall-out from granting agencies and government departments. What we need is an unvexed centre, and we can find it, I think in interdisciplinary work at a high level devoted to Canadian problems. I suggest a group of interdisciplinary seminars at various universities across the country, manned by existing faculty and post-doctoral students, seconded from the area universities for say, two or three years. The seminars would have no function except to concentrate on a particular Canadian problem. It might be wise to insist that for the duration of the seminar the individual should set aside his individual research and abjure attendance at all conferences and professional meetings. We might call this network of seminars our National University, and invite the federal government to act as catalyst and partial paymaster, thus restoring in an irreproachable way a national presence in higher education, whose absence now has, I think, contributed to the appearance of aimlessness in our universities.

My answer, then, to the question of Canadianism in higher education is not staff quotas or major curricular reform, but a concentration of scholarly attention on the highest level, under ideal conditions, on the problems that bedevil us - the old familiar problem of energy resources, of French-English relations, of Canadian-American relations, of our cultural profile - in the hope that we can clear away the debris of confusion, misinformation, and crazy perspectives that grows higher each time we listen to a political speech or read an article. I have urged a national presence, but these seminars that I propose and the universities themselves would remain the primary responsibility and concern of the provinces. They would take place in provincial universities and be staffed by those already appointed to provincial universities. It is a question of the universities reflecting and clarifying the balance between federal and provincial. One of the distinguishing characteristics of our universities has been the capacity to act together, through a national body, a body in which big and small, secular and sectarian, French and English, have worked together harmoniously for common national goals. To be effectively Canadian the universities must never abandon their national concerns and their power to influence national policy.

\section{Notes}

1. These two passages are quoted in Harris, Robin, History Higher Education in Canada 1663-1960, University of Toronto Press, 1976, pp. 28, 29.

2. Harris op. cit., 193, 4. The Falconer quotation comes also from Harris, 100.

3. Notes to an address, University of Toronto, October 27/50 as National Archives, R. G. 33, 28, pp. 1, 1 A. 